\title{
RESISTANCE FACTORS IN SOFTWARE PROCESSES IMPROVEMENT
}

\author{
Josiane Brietzke ${ }^{1}$, Abraham Rabelo ${ }^{1}$ \\ ${ }^{1}$ La Salle University - UNILASALLE, Computer Sciences, Victor Barreto Ave, 2288 \\ 92010-000, Canoas, RS, Brasil \\ josiane brietzke@hotmail.com, rabelo@acm.org
}

\begin{abstract}
Several companies have been carrying out software processes improvement projects. However, some of them give up before the project ends and others take much longer than expected to get it accomplished. This way, identifying the resistance factors that influence the implementation of such projects might serve as a reference to professionals in this area on the one hand, and help to manage future projects on the other, through the use of preventive actions that either lessen or eliminate the resistance factors' consequences. For this matter, this article presents a survey with 36 professionals involved in initiatives of software processes improvement in 18 companies in the state of Rio Grande do Sul, Brazil.
\end{abstract}

\section{Introduction}

The quality of software products is highly related to the quality of the software process (17).

As a consequence of this and the demands of the software market, the companies are establishing software processes improvement projects in order to better the quality of their software products, have a competitive differential in relation to their competitors, enable their entrance in the international market, reduce costs and meet deadlines.

However, there may be many resistance factors influencing the course of a software process improvement project, mainly if these projects are performed in small companies with scant resources.

Moreover, some companies begin but not conclude the project, and others take much longer than expected to get it accomplished.

In this context, this study aims at identifying resistance factors in software processes improvement projects by means of a survey comprising companies in the state of Rio Grande do Sul, Brazil.
The relevance of such a research project relies on the following reasons: it can contribute significantly to the management and control of the resistance factors in future in software processes improvement projects through the implementation of preventive actions; the data found here may serve as reference to professionals involved in projects alike and to researchers in the area of Software Engineering as well. There is little work in the field of software quality sharing this very objective, or either, based on companies' empirical experience.

This article is organized in 7 sections: section 2 introduces a general overview of software process improvement standards; section 3 presents a collection of published experiences concerning resistance factors in software processes improvement; section 4 describes the methodology adopted in this study; section 5 presents the consolidation of research; section 6 analyzes results and section 7 presents final considerations.

\section{Software Processes Improvement}

It is believed that, by improving a software process, one can enhance product quality because, according to Sommerville (22), the 
quality of the process exerts a significant influence on the software quality.

In this section some widely adopted national and international standards will be described, with the main objective of highlighting their focus of action.

Except for CMM (6) and CMMI (7) models, it is observed that the standards presented in this section do not exclude one another, that is, they are complementary.

This evidence is confirmed by $\mathrm{MR}$ mpsBr (20), which developmental basis consists of the union of ISO/IEC 12207 (1), ISO/IEC 15504 (11) regulations and the CMMI Staged Representation (7).

In Table 1, we present a summary of both national and international standards.

\begin{tabular}{|c|c|c|}
\hline Standard & Objective & How \\
\hline $\begin{array}{l}\text { CMM } \\
(\mathrm{SW}-\mathrm{CMM})\end{array}$ & $\begin{array}{l}\text { Providing a } \\
\text { guide of how } \\
\text { to control } \\
\text { software } \\
\text { processes and } \\
\text { instill a } \\
\text { culture of } \\
\text { software } \\
\text { engineering } \\
\text { and } \\
\text { excellence in } \\
\text { the } \\
\text { organization's } \\
\text { management. } \\
\end{array}$ & $\begin{array}{l}\text { By serving key } \\
\text { process areas, } \\
\text { which are } \\
\text { structured in } 5 \\
\text { sequential } \\
\text { maturity levels. }\end{array}$ \\
\hline $\begin{array}{l}\text { ISO/IEC } \\
15504\end{array}$ & $\begin{array}{l}\text { Perform } \\
\text { software } \\
\text { processes } \\
\text { assessments, } \\
\text { aiming at } \\
\text { processes } \\
\text { improvement } \\
\text { and } \\
\text { determining } \\
\text { the processes } \\
\text { capabilities of } \\
\text { an } \\
\text { organization. }\end{array}$ & $\begin{array}{l}\text { Through the } \\
\text { implantation of } \\
\text { processes } \\
\text { related to } \\
\text { software } \\
\text { engineering } \\
\text { and a } \\
\text { measurement } \\
\text { model, which } \\
\text { allows the } \\
\text { assessment of a } \\
\text { certain } \\
\text { process' } \\
\text { capability. }\end{array}$ \\
\hline
\end{tabular}

\begin{tabular}{|c|c|c|}
\hline Standard & Objective & How \\
\hline $\begin{array}{l}\text { CMMI - } \\
\text { Staged } \\
\text { Representation }\end{array}$ & $\begin{array}{l}\text { Providing a } \\
\text { guide to } \\
\text { improve } \\
\text { processes and } \\
\text { empower the } \\
\text { organization } \\
\text { to manage the } \\
\text { development, } \\
\text { acquisition } \\
\text { and } \\
\text { maintenance } \\
\text { of products or } \\
\text { services. }\end{array}$ & $\begin{array}{l}\text { By serving } \\
\text { process areas } \\
\text { structured in } 5 \\
\text { sequential } \\
\text { maturity levels } \\
\text { that allow the } \\
\text { definition of an } \\
\text { organization's } \\
\text { profile as a } \\
\text { whole. }\end{array}$ \\
\hline $\begin{array}{l}\text { CMMI - } \\
\text { Continuous } \\
\text { Representation }\end{array}$ & $\begin{array}{l}\text { Providing a } \\
\text { guide to } \\
\text { improve } \\
\text { processes and } \\
\text { empower the } \\
\text { organization } \\
\text { to manage the } \\
\text { development, } \\
\text { acquisition } \\
\text { and } \\
\text { maintenance } \\
\text { of products or } \\
\text { services. }\end{array}$ & $\begin{array}{l}\text { Through the } \\
\text { refinement of } \\
\text { each process } \\
\text { area. These } \\
\text { process area } \\
\text { are grouped in } \\
\text { categories and } \\
\text { in } 6 \text { levels of } \\
\text { capability that } \\
\text { allow the } \\
\text { definition of } \\
\text { the } \\
\text { organization's } \\
\text { profile in each } \\
\text { process area. }\end{array}$ \\
\hline $\begin{array}{l}\text { NBR ISO/IEC } \\
12207\end{array}$ & $\begin{array}{l}\text { Help defining } \\
\text { the processes } \\
\text { that involve } \\
\text { the software's } \\
\text { life cycle. }\end{array}$ & $\begin{array}{l}\text { Through the } \\
\text { implantation } \\
\text { of processes of } \\
\text { the software's } \\
\text { life cycle, } \\
\text { which must be } \\
\text { adapted to the } \\
\text { organization's } \\
\text { or to the } \\
\text { projects' } \\
\text { characteristics. }\end{array}$ \\
\hline $\mathrm{MR} \mathrm{MpsBr}$ & $\begin{array}{l}\text { Offering the } \\
\text { Brazilian } \\
\text { market a } \\
\text { cheaper } \\
\text { qualification } \\
\text { alternative. }\end{array}$ & $\begin{array}{l}\text { By serving } \\
\text { area process in } \\
7 \text { maturity } \\
\text { levels that } \\
\text { allow reaching } \\
\text { short-term } \\
\text { results. }\end{array}$ \\
\hline
\end{tabular}




\begin{tabular}{|l|l|l|}
\hline Standard & Objective & How \\
\hline NBR ISO & $\begin{array}{l}\text { Meet the } \\
\text { clients' needs, } \\
\text { understand } \\
\text { their current } \\
\text { and future } \\
\text { needs and } \\
\text { exceed their } \\
\text { expectations. }\end{array}$ & $\begin{array}{l}\text { By setting up } \\
\text { Quality } \\
\text { Management } \\
\text { System. }\end{array}$ \\
\hline \\
Table 1. Summary of National and \\
International Standards
\end{tabular}

Section 3 approaches resistance factors in software processes improvement projects that usually use the standards presented in this section as reference.

\section{Resistance Factors in Software Processes Improvement Projects}

This section presents a set of hypotheses concerning resistance factors found in software processes improvement projects, which were identified in accounts of professionals and in previous publications and are classified according to Beecham's research (5).

\subsection{Organizational Factors}

These are related to problems within the scope of the organization and are usually under senior managers' responsibility (2), (3), (4), (5), (8), (12), (23) and (24).

\subsubsection{Human}

This is the most frequently mentioned factor by the authors that report experiences in software processes improvement projects (2), (3), (4), (5), (8), (12), (23) and (24).

According to Abrahamssom (2), the concept of commitment (to the improvement of processes across all levels of the organization) has been one of the most important factors determining whether a well planned improvement process project will succeed.
Although the commitment and support of all management levels are required, the adhesion of the technical staff as a whole is also necessary (5).

In a research carried out in Brazil, the aspects "lack of support from the board of directors" and "lack of coordination and leadership in the implementation activities" were also perceived as critical by the participants (3).

\subsubsection{Political}

By setting up organizational policies, directors make their intentions clear regarding a software processes improvement project and obtain an active and consistent commitment in all managerial levels (23) and (24).

According to Wiegers (24), this can be a way to deal with problems related to project leaders/project managers, for they can manage the urgency in delivering a current product through the reduction of effort, which could point to the improvement of the organization's processes capabilities.

Wheeler (23) also considers the political factor important to the construction of a department to software quality assurance. He states that the commitment of senior managers and leadership are the first step to be taken, followed by the establishment of a quality policy. This policy describes the organizational goals and the objectives related to the quality.

\subsubsection{Cultural}

Although some reference models worry about the creation of a quality culture, this factor requires a lot of skill, because a software processes improvement project will demand cultural changes.

One of Conradi's (8) assumptions concerning this factor is that the accomplishment of such changes implies expertise in social sciences. He complements such idea by saying that 
Engineering, including Software Engineering, mixes both technical and social aspects.

\subsubsection{Goals}

A software processes improvement project must be associated with the organization's strategic goals and objectives (4), (8) and (24).

One of the traps to undermine a software processes improvement project are the management's unrealistic expectations, since the excessive enthusiasm on the part of ambitious managers can also be risky to the improvement program. If the goals, deadlines and expected results are unrealistic, the efforts toward processes improvement may fail (24).

Managers, particularly the little experienced ones, may not appreciate the time and effort involved in software processes improvement. They may focus on issues of pressing importance to them that are not realistic outcomes of processes improvement effort (24).

\subsubsection{Change Management}

Change management must be aligned with the organization's business objectives. For this reason, it is suggested that an initial analysis be made to identify whether the company really needs this sort of project, and whether it matches the organization's interests.

Wiegers (24) also posits that the software processes improvement project's team be used to actively facilitate the efforts toward changes on the part of the project teams rather than simply check the situation of the ongoing process in order to report a long and depressing list of findings (non-conformity).

\subsection{Project Factors}

These factors relate to problems regarding the software process improvement project: planning, activities, resources and, among others (5) and (24).

\subsubsection{Budget and Estimates}

This factor is crucial to the majority of software processes improvement projects, because these projects need financial investment (personnel and equipment) that will return to the organization only on a long-term basis.

Wiegers (24) adds that the lack of progress in improvement plans is frustrating to those who really want to achieve progress, and this belittles the importance of the time and money investments made in the process evaluation.

\subsubsection{Documentation}

In the case of software processes improvement projects, it will be necessary to create an infrastructure to the documentation, since many mandatory practices in the reference models must be documented and formalized in order to objective evidence and dissemination throughout the organization.

According to Beecham's research (5), the documentation is also gaining importance in the list of problems associated to software processes improvement. It includes data measurement, proceedings register, coordination and management of the documentation, data collecting methods and others.

Regarding the documentation factor, Wiegers (24) raises another associated issue: the fact of a small organization loosing the CMM spirit (or any other process model) while trying to apply it to the letter, introducing excessive documentation and formality.

\subsubsection{Tools and Technology}

The problems associated to tools and technology are the second most frequently mentioned concerns on the part of developers and project managers (5). This refers to the implementation of new technologies and tools, amount of work and pressures that hinder the use of new tools. 
In the case of the software processes improvement project, the orientation is to implement the use of tools and technology in a second stage of the process.

\subsubsection{Quality}

This factor refers to the person in charge of the quality or to the quality assurance group in an organization (SQA, PPQA, etc). Most of the times, the main duty of this person or group is to guarantee the institutionalization of the improvement of processes and, because of that, they feel directly the resistance in the implementation of improvements.

According to Pires (16), at first the project teams were reluctant to adopt the new processes and assessments carried out by the SQA group. This problem was solved by involving the senior managers in the process, who motivated their teams by means of lectures and workshops. Furthermore, the SQA group directed its activities more strongly towards supporting the execution of the new process activities.

\subsection{Some Considerations}

The professionals responsible for future software processes improvement projects may include in their planning, more specifically in their risk management, some preventive actions to the factors presented in this section.

Table 2 shows a set of hypotheses concerning resistance factors that are believed to be crucial to software processes improvement, taking the study performed so far as a reference.

\begin{tabular}{|c|c|}
\hline \multicolumn{2}{|l|}{ 1. Organizational Factors } \\
\hline 1.1. Human & 1.2. Political \\
\hline \multirow{3}{*}{$\begin{array}{l}\text { - Lack of commitment } \\
\text { in all levels of the } \\
\text { organization; } \\
\text { - Little adhesion and } \\
\text { participation; } \\
\text { - Professionals short of } \\
\text { experience and skill; } \\
\text { - Lack of leadership } \\
\text { and backup by the } \\
\text { senior management; } \\
\text { - Lack of adequate } \\
\text { training. }\end{array}$} & $\begin{array}{l}\text { - Lack of the } \\
\text { establishment of } \\
\text { organizational policies; } \\
\text { - Lack of establishment } \\
\text { of the Quality policy. }\end{array}$ \\
\hline & 1.3. Cultural \\
\hline & $\begin{array}{l}\text { - Lack of expertise in } \\
\text { implementing cultural } \\
\text { changes. }\end{array}$ \\
\hline 1.4. Goals & $\begin{array}{l}\text { 1.5. Change } \\
\text { Management }\end{array}$ \\
\hline $\begin{array}{l}\text { - Lack of consistency } \\
\text { between the software } \\
\text { processes improvement } \\
\text { project and the } \\
\text { organization's strategic } \\
\text { objectives; } \\
\text { - Absence of focus on } \\
\text { the organization's most } \\
\text { urgent needs; } \\
\text { - Unrealistic } \\
\text { expectations towards } \\
\text { the software processes } \\
\text { improvement project. }\end{array}$ & $\begin{array}{l}\text { - Insufficient and } \\
\text { ineffective assessment } \\
\text { of the current software } \\
\text { process; } \\
\text { - Existence of a } \\
\text { software processes } \\
\text { improvement project } \\
\text { team not focused on } \\
\text { orientation and } \\
\text { technical support; } \\
\text { - Simultaneous focus } \\
\text { on many improvement } \\
\text { areas. }\end{array}$ \\
\hline \multicolumn{2}{|l|}{ 2. Project Factors } \\
\hline $\begin{array}{l}\text { 2.1. Budget and } \\
\text { Estimates }\end{array}$ & 2.2. Documentation \\
\hline $\begin{array}{l}\text { - Current budget } \\
\text { exceeds planning; } \\
\text { - Lack of } \\
\text { understanding, on the } \\
\text { part of senior } \\
\text { management, that the } \\
\text { software processes } \\
\text { improvement project is } \\
\text { a long-term return on } \\
\text { investment process; } \\
\text { - Lack of visibility } \\
\text { about the ongoing } \\
\text { software processes } \\
\text { improvement project } \\
\text { activities. } \\
\end{array}$ & $\begin{array}{l}\text { - Excessive } \\
\text { documentation and } \\
\text { formality; } \\
\text { - Lack of infrastructure } \\
\text { and of a documentation } \\
\text { management; } \\
\text { - Little flexibility in the } \\
\text { use of the } \\
\text { documentation in } \\
\text { projects of different } \\
\text { types and sizes. }\end{array}$ \\
\hline
\end{tabular}




\begin{tabular}{|c|c|}
\hline 2.3. Quality & $\begin{array}{l}\text { 2.4. Tools and } \\
\text { Technology }\end{array}$ \\
\hline $\begin{array}{l}\text { - Lack of involvement } \\
\text { of senior management } \\
\text { in the relationship } \\
\text { between the project } \\
\text { teams and the person or } \\
\text { group of quality } \\
\text { assurance; } \\
\text { - Lack of treatment to } \\
\text { guarantee process } \\
\text { conformity in instances } \\
\text { of hiring and/or } \\
\text { dismissal of skilled } \\
\text { professionals. }\end{array}$ & $\begin{array}{l}\text { - Automatization of not } \\
\text { well defined processes; } \\
\text { - Lack of training on } \\
\text { the support tools and } \\
\text { technologies; } \\
\text { - Pressure and absence } \\
\text { of planning concerning } \\
\text { the adaptation period. }\end{array}$ \\
\hline
\end{tabular}

Table 2. Resistance factors in software processes improvement

Taking this set of assumptions concerning resistance factors as a starting point, we have developed a research project to find out whether they are present in some companies in the state of Rio Grande do Sul, through a survey whose methodology is described in section 4 .

\section{Methodology}

In this section the some aspects of the methodology adopted will be described, drawing on (10), (3) and (15).

The present research project aims primarily at identifying resistance factors in software processes improvement projects through professionals acting in enterprises in Rio Grande do Sul. It is of a quantitative nature and a descriptive character.

The research method comprises two phases, the first one corresponding to a review on prior literature and the second one to a survey.

The element is the professional involved in software processes improvement initiatives. The universe consists of 36 professionals of small, medium and large sized companies located in Porto Alegre, its adjacent areas and also in Sinos Valley in Rio Grande do Sul.
The sample is non-probabilistic and intentional. Therefore, the results of this research project are valid only to the group of companies taking part in the study.

The research instrument consists of a questionnaire based on a theoretical referential, applied to respondents either personally or via email.

In the data analysis, the professionals are characterized according to the attribution of weight to their answers, so that the final results take into consideration the professional's experience.

The Formula 1 shows the calculation to attribute weight to a participant, and tables 3,4 and 5 are examples of scoring table used in the calculation. Where:

$$
\begin{gathered}
P(i)=\operatorname{Max}\{\operatorname{Max}[I(i)] ; \operatorname{Max}[U(i)]\}+\operatorname{Max}\left[F_{1}(i)\right]+ \\
\operatorname{Max}\left[F_{2}(i)\right]+T_{1}(i)+N(i)+T_{2}(i)+E(i) \\
\text { Formula 1. Participant's weight }
\end{gathered}
$$

- P (i) is the total score attributed to participant i. It is a sum of the diverse criteria that the participant characterizes (industry working area, university working area, working time in improvement of software process, etc.) This serves to measure the weight of the opinion of the participant;

- I (i) is the participant score due to his working area in the software development industry, according to Table 3 ;

- $U$ (i) is the score attributed to participant $i$ in relation to his working area at University, according to table 4;

- $F_{1}$ (i) is the score attributed to participant $\mathrm{i}$ according to his academic level;

- $F_{2}$ (i) is the score attributed to participant $\mathrm{i}$ according to his academic area;

- $\mathrm{T}_{1}$ (i) is the score attributed to participant $\mathrm{i}$ according to the time he has been involved in the area of software development;

- $N$ (i) is the score attributed to participant $\mathrm{i}$ according to the number of software processes improvement projects he has taken part in;

- $\mathrm{T}_{2}$ (i) is the score attributed to participant $\mathrm{i}$ according to the time he has worked in the 
area of software processes improvement, according to table 5;

- E (i) is the score attributed to participant $\mathrm{i}$ according to his expertise in software processes improvement.

\begin{tabular}{|l|l|}
\hline Industry working area & I (i) \\
\hline Businessperson & 2 \\
\hline Techology Manager & 2 \\
\hline Quality manager & 4 \\
\hline Project Manager & 3 \\
\hline Software Development Manager & 3 \\
\hline Systems Analyst & 1 \\
\hline SW Quality Analyst & 4 \\
\hline TI Consultant & 3 \\
\hline Programmer & 1 \\
\hline Others & 1 \\
\hline
\end{tabular}

Table 3. Industry working area

\begin{tabular}{|l|l|}
\hline University working área & U (i) \\
\hline Professor & 4 \\
\hline Researcher & 3 \\
\hline Consultant & 3 \\
\hline Doctorate's Student & 2 \\
\hline Master's Student & 1 \\
\hline Undergraduate Student & 0 \\
\hline None & 0 \\
\hline
\end{tabular}

Table 4. University working area

\begin{tabular}{|l|l|}
\hline Working Time & $\mathrm{T}_{2}(\mathrm{i})$ \\
\hline Above 5 years & 4 \\
\hline Between 2 and 5 years & 2 \\
\hline Up to 2 years & 0 \\
\hline
\end{tabular}

Table 5. Scoring according to time worked in software process improvement

Taking both the characteristics of each participant in this research and the scoring tables as a basis,it is possible to calculate the weight of each one through the formula described in Formula 1.

\section{Consolidation of Research}

The present section describes the sample profile and the consolidation and analysis of the data obtained according to section 4 .

\subsection{Sample Profile}

On the whole, 94 companies were contacted and, according to Figure 1, 25,53\% of the contacted companies fit the intended profile, that is, posses a software development department based either in Porto Alegre, its adjacencies or in the Sinos Valley and have already implemented - or are on the way to implement - any software processes improvement project (analyzed in section 2)

It is also observed in Figure 1 that $36,17 \%$ of the companies do not meet all the requirements of the profile desired to this research, that is, they do not possess the characteristics mentioned above. Moreover, it evidences a little significant adoption of initiatives of quality of software in the scene where if it finds the sample of this research inserted.

Some of the contacts made were not successful (e-mails and messages were not replied, could not contact person in charge, etc) and, as a consequence, it is not known whether the contacted company fits the desired profile or not. Figure 1 shows that $38,30 \%$ of the contacted companies fall into this category.

Anyway, 18 out of the 24 companies with the desired profile $(25,53 \%)$ belong to the sample of this research, what accounts for a sample with $75 \%$ of representation.

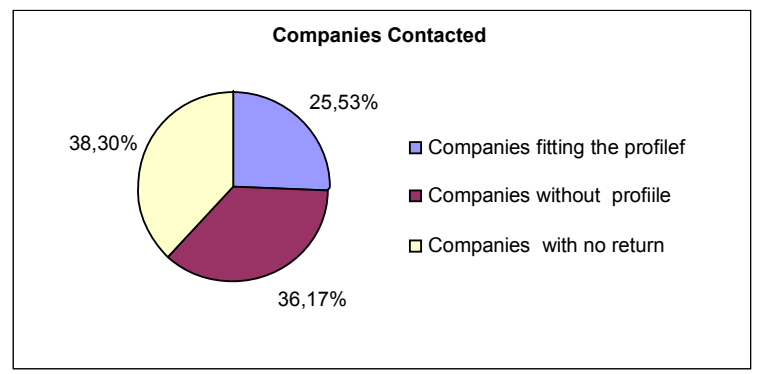

Figure 1. Companies contacted to the survey

The next section shows the consolidation and analysis of the profile of the professionals and companies comprised by this research. 


\subsubsection{The Professionals in the Sample}

The professionals in the sample are characterized according to the following criteria: working area in the software industry and at University; academic background; working time in the software development area; number of projects; working time and experience level in the area of software processes improvement.

We shall now partly characterize the 36 professionals in the sample according to the criteria aforementioned.

The participants work in diverse areas and many of them develop more than one function within the company, as shown in Table 6. Such result mirrors the reality of many Brazilian companies, which lack resources to keep specialized professionals to each working area.

\begin{tabular}{|l|l|}
\hline Working Area & $\begin{array}{l}\text { Number of } \\
\text { participants }\end{array}$ \\
\hline Businessperson & 8 \\
\hline Technology manager & 1 \\
\hline Quality manager & 7 \\
\hline Project manager & 9 \\
\hline Software Development Manager & 5 \\
\hline Systems Analyst & 11 \\
\hline SW Quality Analyst & 2 \\
\hline TI Consultant & 3 \\
\hline Programmer & 2 \\
\hline Others & 3 \\
\hline
\end{tabular}

Table 6. Number of participants per working area

Note: 1. Multiple choice question.

2. The functions of Executive Manager, SQA and Software Development Director were mentioned in the Others category.

In Figure 2, it is observed that there is a higher concentration of experienced participants in a smaller number of software processes improvement projects.

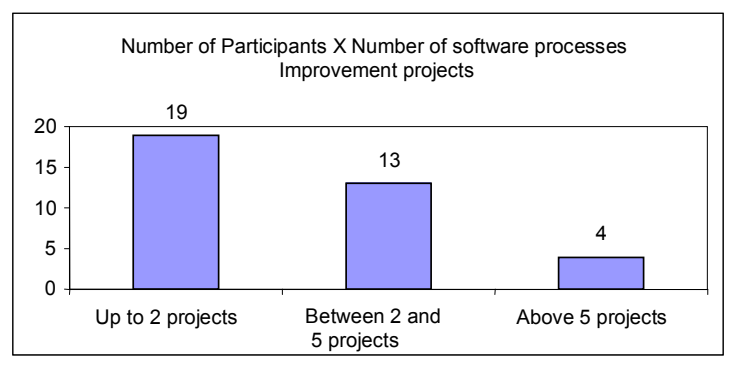

Figure 2. Participants per number of software processes improvement projects.

These results evidence the dificulty on the part of the companies to allocate resources to projects in this area; moreover, in some cases, such projects are not formalized as projects (resources, costs, estimates, etc), being considered as initiatives or improvement programs.

It is evident in Figure 3 a certain homogeneity among participants regarding intervals of working time in the area of software processes improvement.

These results allow us to conclude that the software processes improvement projects last long, and that investments in this area of software engeneering cannot be assumed as something recent.

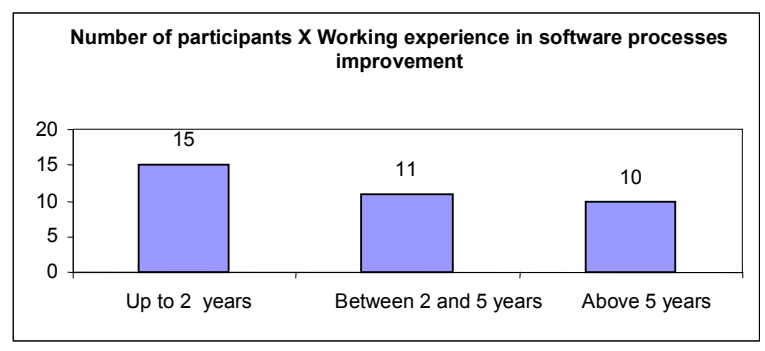

Figure 3. Participants per working time in software processes improvrement

In Figure 4, it can also be noted that the participants in the sample possess a rather satisfactory level of experience in software processes improvrement. 


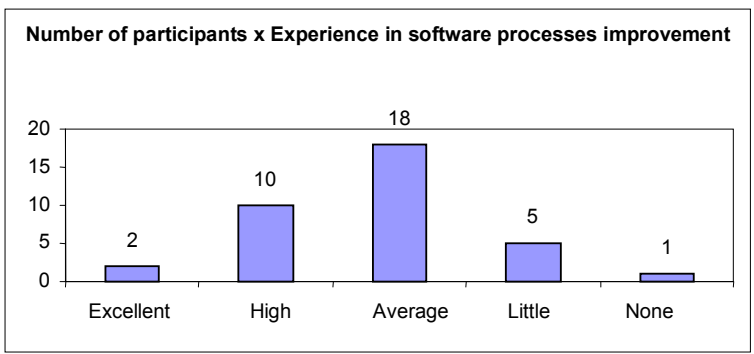

Figure 4. Participants per experience in software processes improvement

\subsubsection{Companies in the Sample}

The companies in the sample are characterized according to the criteria of size, location, activities concerning software treatment, domains, kinds of software application developed and quality standards used as referential to the software processes improvrement projects.

Following, part of the characterization of the 18 companies in the sample is introduced, according to the criteria mentioned above.

Figure 5 depicts the distribution of the companies in the sample according to the size criterium and confirms the predominance of small companies in the sample.

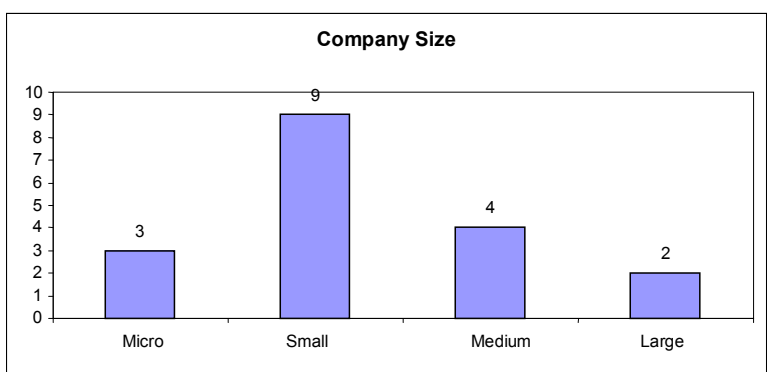

Figure 5. Company size per number of employees

To define de size of the compamies, this study relies on the criterium per number of employees to the Commerce/Services industry defined by SEBRAE/RS (19), as shown in Table 7.

\begin{tabular}{|c|c|c|}
\hline Size & Sector & $\begin{array}{l}\text { Number of } \\
\text { employees }\end{array}$ \\
\hline \multirow{2}{*}{$\stackrel{0}{: 0}$} & Industry & Up to 19 employees \\
\hline & Commerce/Services & Up to 9 employees \\
\hline \multirow{2}{*}{ 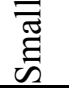 } & Industry & 20 to 99 employees \\
\hline & Commerce/Services & 10 to 49 employees \\
\hline \multirow{2}{*}{$\stackrel{\Xi}{\Xi}$} & Industry & $\begin{array}{l}100 \text { to } 499 \\
\text { employees }\end{array}$ \\
\hline & Commerce/Services & $\begin{array}{l}50 \text { to } 249 \\
\text { employees }\end{array}$ \\
\hline \multirow[b]{2}{*}{ o્d } & Industry & $\begin{array}{l}\text { above } 499 \\
\text { employees }\end{array}$ \\
\hline & Commerce/Services & $\begin{array}{l}\text { above } 250 \\
\text { employees }\end{array}$ \\
\hline
\end{tabular}

Table 7. Ranking of company size per number of employees

As shown in Figure 6, the highest concentration of participant companies is located in Porto Alegre and, in second place, with the same number of companies, the regions surrounding Porto Alegre and Sinos Valley.

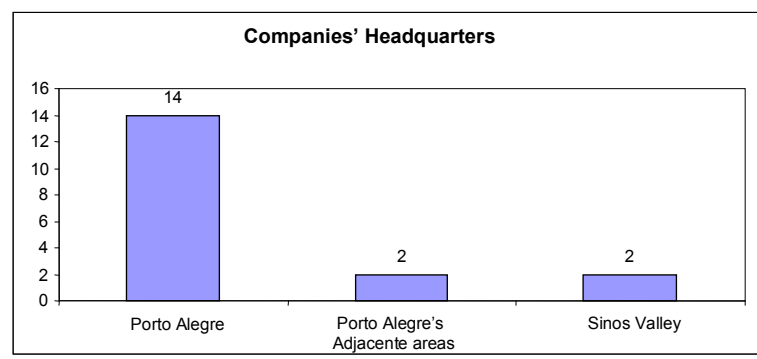

Figure 6. Companies' headquarters per region

It is observed in Table 8 a higher predominance of the CMM (SW-CMM) model adopted as a reference by the majority of the companies in the software processes improvrement projects.

Such a result must be linked to the fact that this model is an older one, and because it is more widely spread in the market. Furthermore, there are many reports published concerning its implementation (5), (8), (13), (18) and (6), as well as actions and projects performed by support entities (9) and (21).

Anyway, this situation is likely to change by the end of this year, since SEI will suspend 
assessments based on this model and operate only with the CMMI model. Most likely, the companies in the sample that are adopting the CMMI model will soon be making the final adjustments to follow this shift $(14,71 \%$ in Staged Representation and 5, 88\% in Continuous Representation).

It can also be seen in Table 8 that other nonstudied standards have also been used as reference by the companies $(20,59 \%)$. And, what is more, the adoption of more than one standard as reference in software processes improvrement projects is common practice across companies.

\begin{tabular}{|l|l|l|}
\hline Standard & $\begin{array}{l}\text { Nunber of } \\
\text { companies }\end{array}$ & $\%$ \\
\hline CMM (SW-CMM) & 13 & 38,24 \\
\hline ISO/IEC 15504 & 1 & 2,94 \\
\hline $\begin{array}{l}\text { CMMI (Staged } \\
\text { Representation) }\end{array}$ & 5 & 14,71 \\
\hline $\begin{array}{l}\text { CMMI (Continuous } \\
\text { Representation) }\end{array}$ & 2 & 5,88 \\
\hline NBR ISSO/IEC 12207 & 2 & 5,88 \\
\hline MR MpsBr & 1 & 2,94 \\
\hline NBR ISSO 9001:2000 & 3 & 8,82 \\
\hline Others & 7 & 20,59 \\
\hline Base (Sample) & 18 & 100,00 \\
\hline
\end{tabular}

Table 8. Standards of software processes improvrement used as reference by the companies

Note: 1. Multiple choice question

2.The following standards were mentioned in the other category: Rational Unified Process (RUP), Own Methodology, PMI/PMBOK, Six Sigma, ISO 90003:2004 and Microsoft Solution Framework (MSF).

\subsection{Consolidation and Analysis of the Data Obtained}

The consolidation and analysis of the data obtained in this section adopt the methodology described in section 4 .

Taking each participant's weight as a departure point, it is possible to determine the frequency distribution in the sample, as shown in Figure 7.

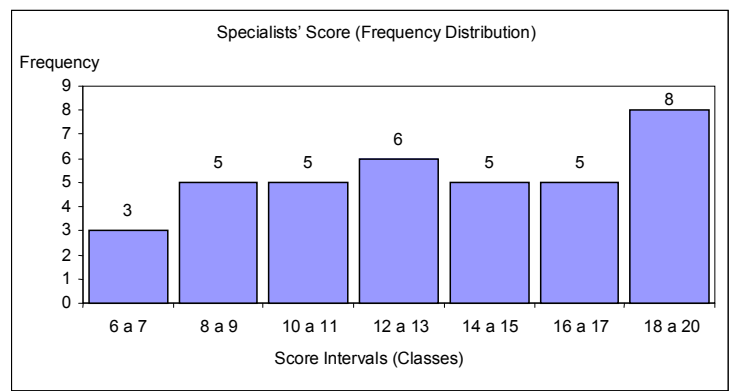

Figure 7. Frequency Distribution of Weight

Besides, this sample shows an average weight of 13,33 , a standard deviation of 4,08 and a variable ratio of $30,61 \%$. Since the standard deviation determines the dispersion of values in relation to the average (14), a high dispersion of the values is confirmed. Moreover, the value of the variable ratio allows us to consider this distribution as an heterogeneous one.

In Figure 7, it can be noted that the participants of the frequency intervals 6 to 7 and 18 to 20 correspond to the participants with lower and higher experience in the area of software processes improvement, respectively.

This differentiation is based on the characteristics of the last interval's participants, because they possess a higher number of projects, more working time and more experience in the the area of software processes improvement than the participants of the first interval.

For this reason, it is necessary to assess the participant's opinion in relation to his experience, so that this factor does not influence the results of the research.

In Table 9, the sample can be divided into quartiles so as to obtain score limits and group the specialists in classes. By this, we can quite increase the sample's degree of homogeneity and diminish the value of the standard deviation of the weights in each class (the dispersion of the values observed is diminished). 
Besides, the possible distortions resulting from the individual comparison among each specialist's weight would be eliminated (15); it would also be possible to consider as nonsignificant the differences of weight among each one of the components (3).

\begin{tabular}{|l|l|}
\hline Quartiles & Score \\
\hline Minimum Value- Q0 & 6 \\
\hline $1^{\text {st }}$ Quartile Limit - Q1 & 10 \\
\hline $2^{\text {nd }}$ Quartile Limit - Q2 & 13 \\
\hline $3^{\text {rd }}$ Quartile Limit - Q3 & 16 \\
\hline $4^{\text {th }}$ Quartile Limit - Q4 & 20 \\
\hline
\end{tabular}

\section{Table 9. Quartiles}

Therefore, in Table 10, it is possible to visualize the specialists grouped in classes (A, $\mathrm{B}, \mathrm{C}$ and $\mathrm{D}$ ), as well as the average and the standard deviation of the weights for those belonging to the same class.

\begin{tabular}{|l|l|l|l|l|}
\hline Class & $\begin{array}{l}\text { Score } \\
\text { Limit }\end{array}$ & Amount & $\begin{array}{l}\text { Mean } \\
\text { Value }\end{array}$ & $\begin{array}{l}\text { Standard } \\
\text { Deviation }\end{array}$ \\
\hline A & Up to 10 & 10 & 8,40 & 1,35 \\
\hline B & $\begin{array}{l}\text { From 11 } \\
\text { to 13 }\end{array}$ & 9 & 11,89 & 0,93 \\
\hline C & $\begin{array}{l}\text { From 14 } \\
\text { to 16 }\end{array}$ & 8 & 15,13 & 0,83 \\
\hline D & $\begin{array}{l}\text { Higher } \\
\text { than 16 }\end{array}$ & 9 & 18,67 & 1,12 \\
\hline
\end{tabular}

Table 10. Specialist Classes

The objective of this division into classes is to attribute a single weight to the answers belonging to the same class, according to table 11 below.

To calculate the weight of each class, the first class is used as a reference (Class A); it is weighed 1,0 and the weight of the others is calculated according to the following formula:

$$
P(j)=\frac{\bar{X}(j)}{\bar{X}(A)}
$$

\section{Formula 2. Participant's weight}

In which:

$P(j)$ is the weight attributed to class $j$;

$X(j)$ is the average weight of class $j$;
$\mathrm{X}(\mathrm{A})$ is the average weight of class $\mathrm{A}$.

\begin{tabular}{|l|l|l|}
\hline Class & Weight Calculation & Weight \\
\hline $\mathrm{A}$ & 1 & 1,00 \\
\hline $\mathrm{B}$ & $11,89 / 8,40$ & 1,42 \\
\hline $\mathrm{C}$ & $15,13 / 8,40$ & 1,80 \\
\hline $\mathrm{D}$ & $18,67 / 8,40$ & 2,22 \\
\hline
\end{tabular}

Table 11. Weight per class of specialist

As one can observe in the table above, the other classes have their weight calculated as a function of the percentage distance of the average weight of the professionals of the class in relation to the average weight of the professionals in class A.

Therefore, the weight of class B is calculated as a function of the number of professionals in class A necessary to equal the weight of a single professional in class B. Likewise, the weight of class $\mathrm{C}$ is determined as a function of the number of professionals in class A necessary to equal the weight of a single professional in class $\mathrm{C}$ and so on.

\section{Results Analysis}

The present section shows the consolidation and the analysis of results obtained in the survey performed from March $21^{\text {st }}$ to May $6^{\text {th }}, 2005$ with the sample described in section 5.1.

In order to consolidate the data obtained, each vote was calculated according to the weight of the class it belonged to, and a normalization was applied to the total of votes of each factor, so that they could be presented in Figures 8 and 9.

These figures present the partial result of the resistance factors in software processes improvement projects, that is, the 3 most and least voted factors, which will be analyzed as follows. 


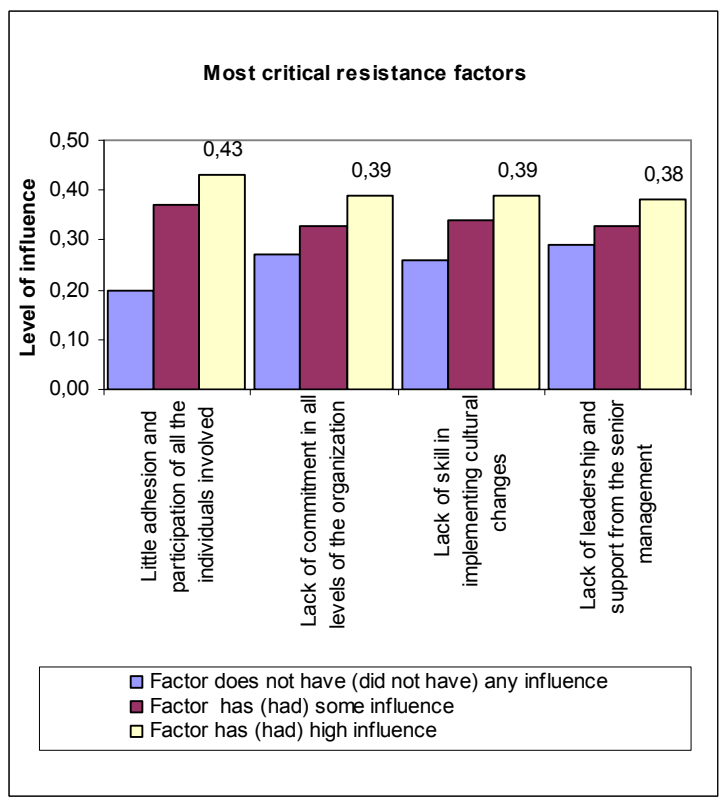

Figure 8. Most critical resistance factors

In Figure 8, it is possible to see that the factor considered as the most critical by the participants in a software processes improvement project is Little adhesion and participation of all the individuals involved. This results corroborates the great influence of the human factor in such an initiative and is in accordance with the results obtained in the literature (presented in section 3.1.1).

According to participants, the second most important factors were Lack of commitment in all levels of the organization and Lack of skill in implementing cultural changes.

Regarding this second position, the participants also show some concern with the human factor, although they report some concern with the organization's culture and it is in accordance with the gotten one of literature in section 3.1.3.

These two factors fall into a broader classification, the organizational factor. At this point, the importance of the organization's capability to operate and adapt to changes is noted.

Besides, the factor Lack of skill in implementing cultural changes is directly influenced by the resources the company possesses to implement the necessary changes.

This factor helps to stress the issue of the size of the company, because the larger the size of a company, the more resources it will be able to allocate to operate the cultural change demanded by such a project.

The third most critical factor was Lack of leadership and support from the senior management. This factor highlights the importance given by the respondents to the senior management support and leadership in the implementation of improvements and it is in accordance with the results gotten in the research of Andrade (2).

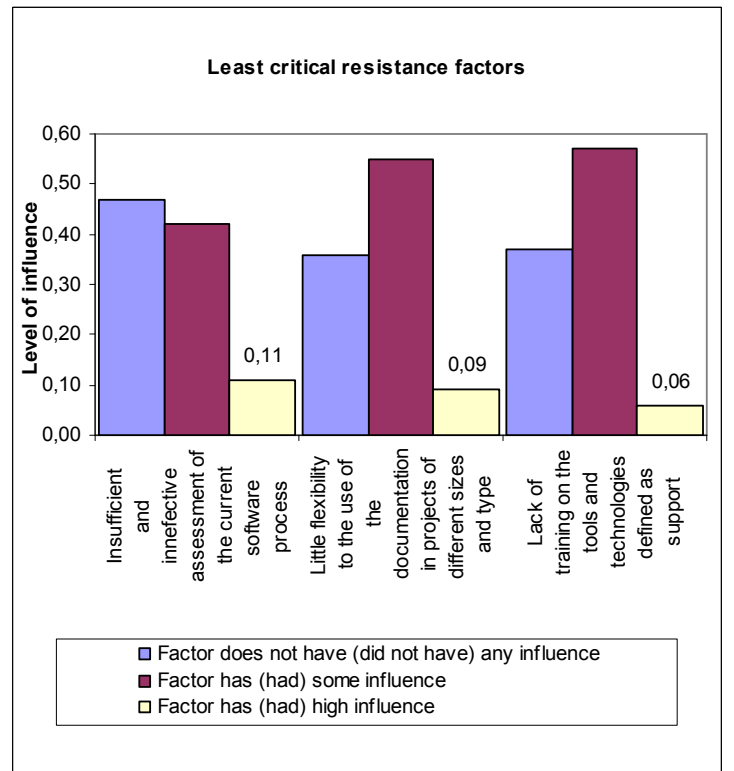

Figure 9. Least critical resistance factors

Figure 9 shows that the factors considered least influent in a software processes improvement project are, respectively: Lack of training on the tools and technologies defined as support, Little flexibility to the use of the documentation in projects of different sizes and types and Insufficient and ineffective assessment of the current software process.

These factors might have been considered least influential by the participants due to the easyness of executing actions to deal with them. 
The factors Lack of training on the tools and technologies defined as support and Little flexibility to the use of the documentation in projects of different sizes and types fall into the classification of project factor, having a smaller scope and being more easily dealt with, that is, they do not involve organizational factors whose treatment is more complex.

From any form, the factor Lack of Training on the tools and technologies defined as support to be pointed with lesser influence differ from the results of the research of Beecham (4).

The factor Insufficient and innefective assessment of the current software process might have been considered less risky because such assessments are usually accomplished by specialists who make use of well-known process assessment methods.

However, this result differs from the concern and the risk pointed for Wiegers (11) with respect to this factor.

From the results obtained, it is observed that the final set of factors equals the initial one, since none of the factors added achieved a total of votes higher than half of the maximum value of votes to one of the factors.

The repetition of this research with another sample of enterprises (situated in other regions of Rio Grande do Sul or in other states of Brazil, for example) could allow a comparative analysis of the results obtined in this sample.

This is due to the absence of related studies, which could serve as a basis to this comparison and to the verification of results.

\section{Final Considerations}

This article presents a set of resistance factors identified in software processes improvement projects, that is, it presents the factors of influence in the transition phase from the current software process to the improved one within the companies.
It is concluded from this study that a software processes improvement project may use more than a standard as reference, since they can be complementary due to the differentiation in focus of action and of the roles involved.

This evidence is confirmed by the analysis of Table 1 and the consolidation of the data presented in Table 8, which used a multiple choice question and were given more than one standard by the participants.

One of the limitations of this research project is that since it adopted a questionnaire as a data collection instrument, it is not always possible to trust the veracity of the information provided, thus diminishing the degree of reliability of the answers given.

Another limitation lies on the size of the sample, that could be increased and applied to other places within the state, were the deadlines more stretched.

On the other hand, this methodology presents an advantage that is its high degreeof flexibility, since it can be applied in other reserch projects with qualitative data and in other fields of science as well, provided that both the criteria and the scoring tables be adapted (because they characterize a participant).

With respect to the data collection stage, we can point out another limitation to this research project: most of the times the gathering occoured via e-mail, thus hindering a closer approach to the filling out of the questionnaire; it was also impossible to learn about the implementation strategy of software processes improvement.

In further studies, this research could be performed in other regions and/or states in the country, what would allow a comparative analysis of the results obtained and a verification of the influence exerted by the cultural factor.

Another suggestion to further studies would be the one of preventive actions to cope with some factors and the implementation of such actions in some organizations, in order to check whether the results would be positive or not. 
As a main contribution, we expect that the results shown in this research project may serve as reference to the professionals involved in software processes improvement projects and to researchers in the field of Software Engineering.

It is also expected that these results may contribute to the planning of future software processes improvement projects, in which preventive actions can be designed to lessen or eliminate their consequences.

Anyway, an initial analysis on the risk of these factors is of paramount importance, for the impact and the probability of an associated risk occur may vary across organizations.

\section{References}

[1] ABNT. Associação Brasileira de Normas Técnicas, 2001. Available at http://www.abnt.org.br (24/03/2006).

[2] Abrahamsson, Pekka. "Commitment Development in Software Process Improvement: Critical Misconceptions". International Conference on Software Engineering, 2001. Available at http://doi.ieeecomputersociety.org/10.1109/IC SE.2001.919082 (24/03/2006).

[3] Andrade, Jean M.; Albuquerque, Adriano B.; Campos, Fábio B.; Rocha, Ana Regina C. "Conseqüências e Características de um Processo de Desenvolvimento de Software de Qualidade e Aspectos que o influenciam: uma avaliação de especialistas". Simpósio Brasileiro de Qualidade de Software, 2004.

[4] Basili, Victor R.; McGarry, Frank E.; Pajerski, Rose; Zelkowitz, Marvin V. "Lessons learned from 25 years of process improvement: The Rise and Fall the NASA Software Engineering Laboratory". International Conference on Software Engineering, 2002. Available at http://doi.acm.org/10.1145/581339.581351 (24/03/2006).

[5] Beecham, Sarah; Hall, Tracy; Rainer, Austen. "Software Process Improvement Problems in Twelve Software Companies: An Empirical Analysis". Empirical Software Engineering, 2003. Available at
http://www.kluweronline.com/article.asp?PIP $\mathrm{S}=5110954$ (24/03/2006).

[6] CMM. Capability Maturity Model, 1993. Available at http://www.sei.cmu.edu/cmm (24/03/2006).

[7] CMMI. Capability Maturity Model Integration, 2002. Available at http://www.sei.cmu.edu/cmmi (24/03/2006).

[8] Conradi, Reidar; Fuggeta, Alfonso. "Improving Software Process Improvement"., IEEE Software, 2002. Available at http://citeseer.ist.psu.edu/cache/papers/cs/265 55/http:zSzzSzwww.idi.ntnu.nozSzgrupperzS zsuzSzpublzSzpdfzSzieeesw-2001final.pdf/conradi02improving.pdf (24/03/2006).

[9] ESICENTER. ESICenter UNISINOS, 2003. Available at http://www.esicenter.unisinos.br (24/03/2006).

[10] Farias, Luciana de Landa. "Planejamento de Riscos em Ambientes de Desenvolvimento de Software Orientados à Organização". Master's dissertation COPPE/UFRJ. 106-130. 2002.

[11] ISO/SPICE, 2003. Available at http://www.isospice.com (24/03/2006).

[12] Iversen, Jakob; Nielsen, Peter A.; Norbjerg, Jacob. "Problem Diagnosis Software Process Improvement". T. J. Larsen, L. Levine, J.I. DeGross (eds.) Information systems: Current Issues and Future Changes IFIP, 1998. Available at http://citeseer.ist.psu.edu/cache/papers/cs/129 21/http:zSzzSzis.1se.ac.ukzSzhelsinkizSzivers en.pdf/iversen98problem.pdf (24/03/2006).

[13] Marczak, Sabrina; Audy, Jorge; Sá, Luciana. "Proposta e aplicação de um instrumento de acompanhamento da implantação do SW-CMM Nível 2". Simpósio Brasileiro de Qualidade de Software, 2005.

[14] Nazareth, Helenalda R. de S. "Curso básico de estatística". Àtica. 10. São Paulo, Brasil. 114. 1998.

[15] Nogueira, Mauro O., Rocha, Ana Regina C. "Práticas Relevantes em Engenharia de Software: uma avaliação de especialistas". Simpósio Brasileiro de Qualidade de Software, 2003.

[16] Pires, Carlos Giovano et al. "A experiência de melhoria do processo do Instituto Atlântico 
baseado no SW-CMM nível 2". Simpósio Brasileiro de Qualidade de Software, 2004.

[17] Rocha, Ana Regina C.; Maldonado, José Carlos; Weber, Kival Chaves. "Qualidade de Software Teoria e Prática". Prentice Hall. 1. São Paulo, Brasil. 1-2. 2001.

[18] Scheible, Alba; Bastos, Antônio Virgílio. "CMM e Comprometimento: Um estudo de caso na implantação do nível 2". Simpósio Brasileiro de Qualidade de Software, 2005.

[19] SEBRAE. Serviço de Apoio às Micro e Pequenas Empresas do Rio Grande do Sul, 2004. Available at http://www.sebraers.com.br, $(24 / 03 / 2006)$

[20] SOFTEX. Associação para Promoção da Excelência do Software Brasileiro, 2005. Available at http://www.softex.br/mpsbr (24/03/2006).

[21] SOFTSUL. Sociedade Sul-riograndense de Apoio ao Desenvolvimento de Software, 2001. Available at http://www.softsul.org.br (24/03/2006).

[22] Sommerville, Ian. "Engenharia de Software". Addison Wesley. 6. São Paulo, Brasil. 477. 2003.

[23] Wheeler, Sharon; Duggins, Sheryl. "Improving Software Quality". ACM Southeast Regional Conference, 1998. Available at http://doi.acm.org/10.1145/275295.275375 (24/03/2006).

[24] Wiegers, Karl E. "Software Process Improvement: Ten Traps to Avoid". Software Development, 1996. Available at http://citeseer.ist.psu.edu/cache/papers/cs/128 48/http:zSzzSzwww.processimpact.comzSzar ticleszSzspitraps.pdf/wiegers96software.pdf (24/03/2006). 